\title{
Experience-based behavioral and chemosensory changes in the generalist insect herbivore Helicoverpa armigera exposed to two deterrent plant chemicals
}

\author{
Dongsheng Zhou • Joop J. A. van Loon • \\ Chen-Zhu Wang
}

Received: 16 April 2010/Revised: 29 June 2010/Accepted: 30 June 2010/Published online: 13 July 2010

(C) The Author(s) 2010. This article is published with open access at Springerlink.com

\begin{abstract}
Behavioral and electrophysiological responses of larvae of the polyphagous moth species Helicoverpa armigera to two plant-derived allelochemicals were studied, both in larvae that had been reared on a diet devoid of these compounds and in larvae previously exposed to these compounds. In dual-choice cotton leaf disk and pepper fruit disk arena assays, caterpillars reared on a normal artificial diet were strongly deterred by strychnine and strophanthinK. However, caterpillars reared on an artificial diet containing strychnine were insensitive to strychnine and strophanthin-K. Similarly, caterpillars reared on an artificial diet containing strophanthin-K were also desensitized to both deterrent chemicals. Electrophysiological tests revealed that the deterrent-sensitive neurons in taste sensilla on the maxillae of caterpillars reared on each deterrent-containing diet displayed reduced sensitivity to the two chemicals compared with the caterpillars reared on normal diets. We conclude that the experience-dependent behavioral plasticity was partly based on the reduced sensitivity of taste receptor neurons and that the desensitization of taste receptor neurons contributed to the crosshabituation to the two chemicals.
\end{abstract}

Keywords Deterrent neuron - Sensilla styloconica . Food experience - Acquired insensitivity .

Cross-habituation

\author{
D. Zhou $\cdot$ C.-Z. Wang $(\bowtie)$ \\ Institute of Zoology, The Chinese Academy of Sciences, \\ 1 Beichen West Road, Chaoyang District, Beijing 100101, \\ People's Republic of China \\ e-mail: czwang@ioz.ac.cn \\ D. Zhou · J. J. A. van Loon \\ Laboratory of Entomology, Wageningen University, \\ P.O. Box 8031, 6700 EH Wageningen, The Netherlands
}

\section{Introduction}

All animals possess chemosensory systems which can detect chemical substances in their surroundings. The taste system of insects can detect a wide range of dissolved chemicals in potential food substrates and is important for assessing the quality of food resources (Dahanukar et al. 2005). About 50\% of the ca. 1 million known insect species are plant feeders that are confronted with chemically diverse plant metabolites. There are many unpalatable compounds produced by plants used as food by insects in nature, and these co-occur in the same tissues as plantproduced nutrients (Hugentobler and Renwick 1994). These compounds have been named deterrents or suppressors, and elicit an aversive behavioral response in insects (Glendinning et al. 2001a). Therefore, taste discrimination among the complex chemical profiles encountered in plant tissues serves an essential function in host-plant selection of herbivorous insects (van Loon et al. 2008).

Lepidopteran larvae obtain contact chemical information from food by using taste neurons in three sets of taste sensilla located on their mouthparts: the labrum, the maxillary palps and the maxillary galea (Schoonhoven and van Loon 2002; Miles et al. 2005). The eight taste neurons innervating the lateral and medial sensilla styloconica on the maxillary galea play a decisive role in food selection behavior. Taste neurons in the two sensilla styloconica of several caterpillar species have been classified according to their best stimulus as sugar cell, water cell, salt cell, amino acid cell, inositol cell, deterrent cell, etc. (Schoonhoven and van Loon 2002). All herbivorous insects have deterrent cells, the activation of which leads to an aversive behavioral response (Bernays and Chapman 1987; Chapman and Bernays 1989; Dethier 1993; Bernays et al. 2000; 
Schoonhoven and van Loon 2002). It has been well documented that oligophagous insects such as Manduca sexta and Pieris rapae show behavioral adaptation to foods containing deterrent compounds (Schoonhoven 1969; Glendinning and Gonzalez 1995; Huang and Renwick 1995a; Renwick and Huang 1996; Glendinning et al. 2001a). In several cases, experience-induced changes in behavior could be related to the reduced sensitivity of deterrent cells (Schoonhoven 1969; van Loon 1990; Glendinning and Hills 1997; Glendinning et al. 1999, 2001a; Zhou et al. 2009). This has been interpreted as the result of "peripheral memory" located in the taste neurons (Schoonhoven and van Loon 2002). In addition, the experience-induced behavioral change upon exposure to certain compounds can generalize to other compounds that were not experienced before (Schoonhoven 1978; Glendinning et al. 1999). This phenomenon has been termed "cross-habituation" (Huang and Renwick 1995b, 1997). However, the mechanisms underlying such taste-mediated diet-induced behavioral plasticity are poorly understood.

The cotton bollworm Helicoverpa armigera (Lepidoptera: Noctuidae) is a typical polyphagous insect pest in China and many other countries, feeding on more than 200 crops in more than 40 plant families (Fitt 1989; Chen 1999; Zhao et al. 2006). In this study we report behavioral and electrophysiological responses of $H$. armigera caterpillars that experienced normal artificial diet or artificial diet containing two structurally different deterrent chemicals. We addressed two questions: (1) do habituation and "crosshabituation" occur in this generalist when exposed to deterrents during their larval development? (2) does exposure to deterrents affect gustatory responsiveness?

\section{Materials and methods}

\section{Diets}

Three types of diets were used: a normal artificial rearing diet (Wu and Gong 1997) and two experimental diets: the normal diet to which either strychnine or strophanthin-K was added at a concentration of $0.2 \mathrm{mM}$. Preliminary tests had shown that this concentration allowed sufficiently high survival rates (over 70\%). The chemicals were added to the diet just after heating the agar, and the mixture was stirred vigorously for about 2-3 min (modified from Glendinning et al. 1999). The diets were cut into blocks to feed the caterpillars from neonates to the fifth instar.

\section{Insects}

Laboratory colonies of $H$. armigera were maintained as continuous cultures in the laboratory in an environmental chamber under a L16:D8 photo:scotoperiod, at a temperature of $25 \pm 1{ }^{\circ} \mathrm{C}$ and RH $60-70 \%$. Larvae were reared individually in glass tubes plugged with cotton wool on the normal artificial diet. Adults were kept in cages and supplied with a $10 \%$ solution of honey in water. Larvae subjected to behavioral bioassays and electrophysiological tests were reared from neonate to fifth instar on normal artificial diet or diet containing one of the two chemicals. Caterpillars for behavioral assays were taken from the rearing diets at the end of the 4th instar in the non-feeding premoult stage and were deprived of food for about $6-8 \mathrm{~h}$ after moulting to the fifth instar and then tested (Tang et al. 2006).

\section{Chemicals}

Sucrose, inositol, strychnine-HCl and strophanthin-K were obtained from Sigma Chemical Co. (purity $>97 \%$ ). Strophanthin- $\mathrm{K}$ is a mixture of $\mathrm{K}$-strophanthin- $\beta, \mathrm{K}$-strophanthoside and other glucosides of cymarin (5\% cymarin, $80 \%$ $\mathrm{K}$-strophanthoside and 15\% strophoside). For electrophysiological tests, strychnine and strophanthin-K were dissolved in $2 \mathrm{mM} \mathrm{KCl}$, which served as control solution.

\section{Behavioral bioassays}

Two types of substrate were used in dual-choice disk tests: pepper fruit disks and cotton leaf disks. Cotton plants [Gossypium arboreum L., (Malvaceae) cultivar 'Zhong12'] were grown in the greenhouse of Wageningen University; pepper [Capsicum frutescens L. (Solanaceae), cultivar 'JingTian-5'] was grown in the greenhouse of Daxing Agricultural Station in Beijing. In each assay, 20 caterpillars were tested. Strychnine and strophanthin-K were dissolved in $1 \%$ Tween-20 for use. Five microliters of solution of the test compounds was applied on a disk $\left(78.5 \mathrm{~mm}^{2}\right)$. Taking the pepper disk fresh weight/cotton leaf disk fresh weight into account, the concentration of strychnine and strophanthin-K tested was $2 \mathrm{mM}$. The experiments were carried out in a climatic chamber at a temperature of $25 \pm 1^{\circ} \mathrm{C}$. Larvae were placed individually in the middle of Petri dishes (diameter $12 \mathrm{~cm}$ ) lined with moist filter paper. Four treated and four control disks were alternately arranged in an $\mathrm{ABABABAB}$ fashion around the circumference of the Petri dishes. This arrangement was modified after earlier studies to ensure that larvae had an equal chance of encountering both treated and control disks (Wang et al. 2004; Tang et al. 2006). Consumption was observed at hourly intervals thereafter. When ca. $50 \%$ of the control disks or treated disks had been eaten, which took 4-6 h, the disk remains were digitally scanned using a Hewlett-Packard flatbed scanner. Disk surface area was measured using Scion Image for Windows 4.03 (freeware, 
Scion Co. http://www.scioncorp.com/). The areas consumed were calculated by subtracting the remaining areas of leaf disks from the average area of three reference disks, which served as shrinkage controls (Messchendorp et al. 1996).

\section{Electrophysiology}

Caterpillars for electrophysiological tests were fifth instar larvae that had finished ecdysis $24-48 \mathrm{~h}$ earlier and had been starved for $2 \mathrm{~h}$ before testing (van Loon and Schoonhoven 1999). Three groups of larvae were tested: caterpillars reared from neonate to fifth instar on normal artificial diet or on diet containing one of the two chemicals. For each case, 12 replications were performed. Sucrose and inositol were tested at $10 \mathrm{mM}$ on lateral and medial sensilla styloconica, respectively (Tang et al. 2000). For dose-response tests of the normal diet-reared caterpillars, the concentrations of the two chemicals tested were $0,0.01,0.1,1$ and $10 \mathrm{mM}$. For tests on caterpillars reared on the diets containing strychnine or strophanthin$\mathrm{K}$, the concentrations of the two chemicals were $0,0.1,1$ and $2 \mathrm{mM}$. The tip-recording technique (Hodgson et al. 1955) was used to record responses to the different stimuli from the sensilla styloconica on the maxillary galea. Excised caterpillar heads were mounted on a silver wire electrode that was connected to the input of a pre-amplifier (Syntech Taste Probe DTP-1, Hilversum, The Netherlands). Stimulus solutions were filled into glass micropipettes with a tip diameter of c. $30 \mu \mathrm{m}$. Amplified signals were digitized by an A/D-interface (Syntech IDAC-4) and sampled into an Intel Pentium-based personal computer. Electrophysiological responses were quantified by counting the number of spikes in the first $1,000 \mathrm{~ms}$ after the start of stimulation. Spikes were counted visually by the experimenter with the aid of Autospike version 3.7 software (Syntech).

\section{Statistical analysis}

A feeding deterrent index (FDI) $=100(C-T) /(C+T)$ was calculated to quantify the strength of deterrence, where $C$ represents the leaf disk area consumed from control disks, and $T$ represents the leaf disk area consumed from treated disks.

Paired $t$ tests were performed to analyze the disk consumption data. In electrophysiological tests, normal diet-reared caterpillars and deterrent-exposed caterpillars are independent samples; thus, a two-sample $t$ test was performed to compare electrophysiological responsiveness of insects reared on different diets. All statistical analyses were conducted using SPSS 13.0 (SPSS Inc., Chicago, IL).

\section{Results}

Behavioral assays

Larvae reared on normal artificial diet were strongly deterred by strychnine applied either on cotton leaf disks (FDI $=49.3 ; P<0.01$; Fig. 1a) or on pepper fruit disks (FDI $=39.4 ; P<0.01 ;$ Fig. $1 \mathrm{c})$. However, larvae reared on artificial diet containing strychnine did not discriminate between cotton leaf disks or pepper fruit disks treated with strychnine and disks treated with solvent only (FDI $=2.4$, $P>0.05$ on cotton leaf disk substrates; Fig. 1a; FDI $=3.2, \quad P>0.05$ on pepper fruit disk substrates; Fig. 1c). Similarly, normal diet-reared caterpillars were sensitive to strophanthin-K either on cotton leaf disk substrates (FDI $=72.7 ; P<0.001$; Fig. 1b) or on pepper fruit disk substrates $(\mathrm{FDI}=40.6 ; P<0.01$; Fig. $1 \mathrm{~d}$ ). In contrast, for caterpillars reared on the artificial diet containing strophanthin-K, the surface area consumed of cotton leaf disks or pepper disks did not differ significantly between control and strophanthin-K treated disks (FDI $=3.8$, $P>0.05$ on cotton leaf disks; Fig. $1 \mathrm{~b} ;$ FDI $=-5.7$, $P>0.05$ on pepper fruit disks; Fig. 1d). Furthermore, caterpillars reared on artificial diet containing strychnine did not discriminate between pepper disks treated with strophanthin-K or with solvent (FDI $=2.0 ; P>0.05$; Fig. 1e). Likewise, caterpillars reared on artificial diet containing strophanthin-K were insensitive to strychnine $($ FDI $=6.6 ; P>0.05$; Fig. 1e).

\section{Electrophysiological responses}

Strychnine and strophanthin-K elicited relatively weak responses from the lateral sensilla styloconica. Response frequency of strychnine increased significantly from 0.01 to $0.1 \mathrm{mM}$; the response frequency of strophanthin- $\mathrm{K}$ increased significantly from 0.1 to $1 \mathrm{mM}$. The two chemicals elicited strong responses from the medial sensilla styloconica of the normal diet-reared caterpillars (Figs. 2a, $\mathrm{b}, 4 \mathrm{~b}$, e, respectively), demonstrating that this sensillum contains deterrent neurons that are considerably more sensitive to strychnine and strophanthin-K than neurons in the lateral sensillum. The deterrent neurons in the medial sensilla styloconica of caterpillars reared on artificial diet containing strychnine were significantly less sensitive to strychnine than in those of caterpillars reared on normal artificial diet when tested at $0.1,1$ and $2 \mathrm{mM}(P<0.05$, Figs. 2c, 4c). Deterrent taste neurons of caterpillars reared on artificial diet containing strophanthin-K also produced significantly weaker responses to 0.1 and $1 \mathrm{mM}$ strychnine than caterpillars reared on normal artificial diet $(P<0.01$, $P<0.05$, respectively, Figs. 2c, 4d). Similarly, $H$. armigera reared on artificial diet containing strychnine were 

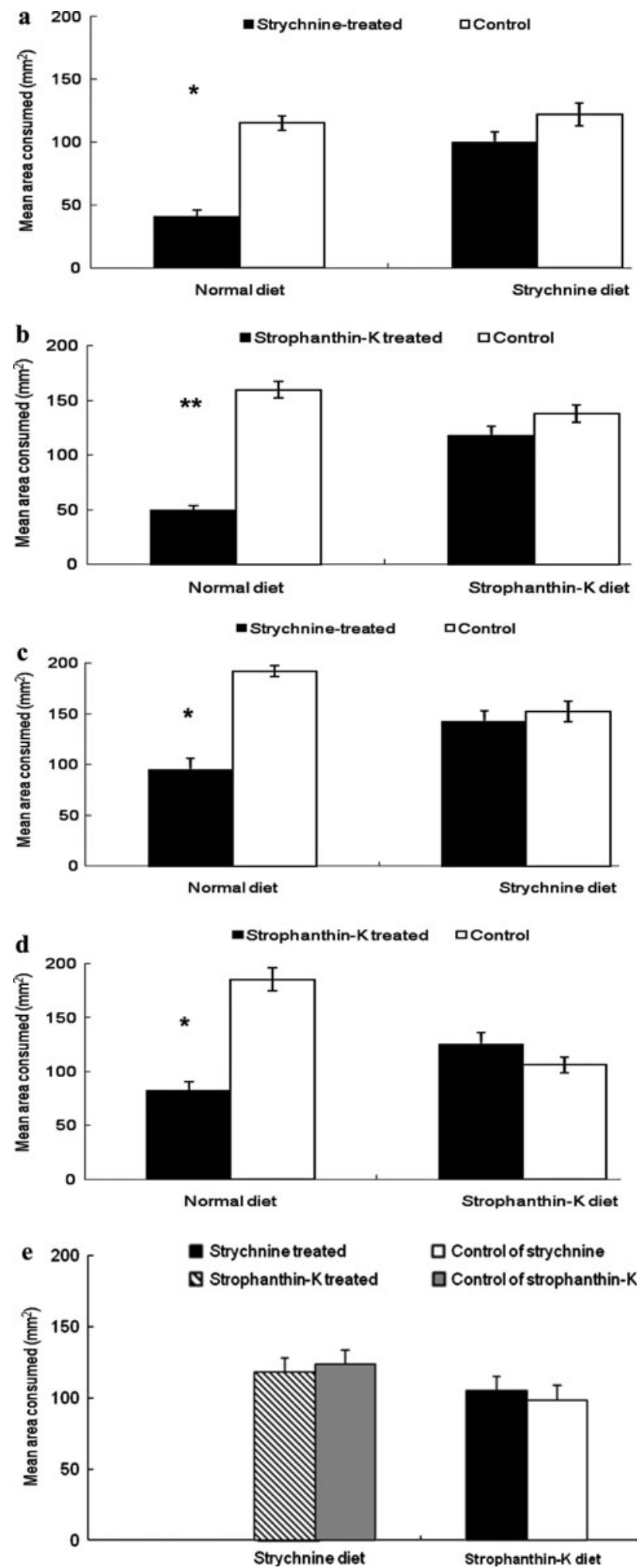

significantly less sensitive to 1 and $2 \mathrm{mM}$ strophanthin- $\mathrm{K}$ compared with caterpillars reared on normal artificial diet $(P<0.05, P<0.001$, respectively; Figs. 2d, 4f). Caterpillars reared on artificial diet containing strophanthin-K
4 Fig. 1 Feeding preference behavior of fifth instar H. armigera larvae, reared on normal artificial diet, strychnine diet or strophanthin-K diet (indicated along the horizontal axis), on cotton leaf disks or pepper fruit disks in choice assays between control and the two chemicals. a Strychnine on cotton leaf disks b strophanthin-K on cotton leaf disks; c strychnine on pepper fruit disks; $\mathbf{d}$ strophanthin-K on pepper fruit disks; e strychnine and strophanthin- $\mathrm{K}$ on pepper fruit disks. $N=20$ in all tests. Vertical lines represent standard errors. Asterisks indicate significant differences between treated and control disks according to the paired-samples $t$ test $\left({ }^{*} P<0.01 ; * * P<0.001\right)$

also had significantly weaker responses to $0.1,1$ and $2 \mathrm{mM}$ strophanthin-K compared with caterpillars reared on normal artificial diet $(P<0.01, P<0.05, P<0.01$, respectively; Figs. 2d, 4g). Furthermore, strychnine elicited responses from only one neuron in medial sensilla styloconica (Fig. 4b). However, strophanthin-K elicited responses from two neurons in medial sensilla styloconica, a more abundant larger amplitude spike type and a less abundant smaller amplitude spike type (Fig. 4e). The mixture of strychnine and strophanthin- $\mathrm{K}$ also elicited responses in which the same two spike types were observed, demonstrating that the neuron producing the more abundant and larger amplitude of the two spike types activated by strophanthin- $\mathrm{K}$ is the neuron responding to strychnine (Fig. 4b, e, h). Further analysis showed that the spike frequency of the neuron responsive to strychnine in the caterpillars reared on strychnine or strophanthin- $\mathrm{K}$ diet was significantly decreased when compared with normal diet-reared caterpillars $(P<0.01$; Fig. $2 \mathrm{e})$. However, the spike frequency of the neuron producing the less abundant smaller amplitude spikes did not differ significantly between caterpillars reared on normal diet and those reared on the diets containing the deterrents $(P>0.05$; Fig. $2 \mathrm{e})$. Sucrose elicited equally strong responses from the lateral sensilla styloconica irrespective of the diet to which the caterpillars had been exposed (Fig. 3). Similarly, responses of the inositol-sensitive neuron in the medial sensilla styloconica were equal for the caterpillars reared on the three different diets (Figs. 3, 4).

\section{Discussion}

Current theory holds that animals make decisions about the selection of mates, kin or food on the basis of preconstructed recognition templates. These templates can be innate or acquired through experience (Sherman et al. 1997). The specialist caterpillar $P$. rapae reared on artificial diet was much less sensitive to several deterrents such as chlorogenic acid, cymarin, erysimoside and $2-O-\beta$-D-glucosyl cucurbitacin $\mathrm{E}$ when compared with cabbage-reared caterpillars, and the compounds responsible for this difference have been identified in the wheat 

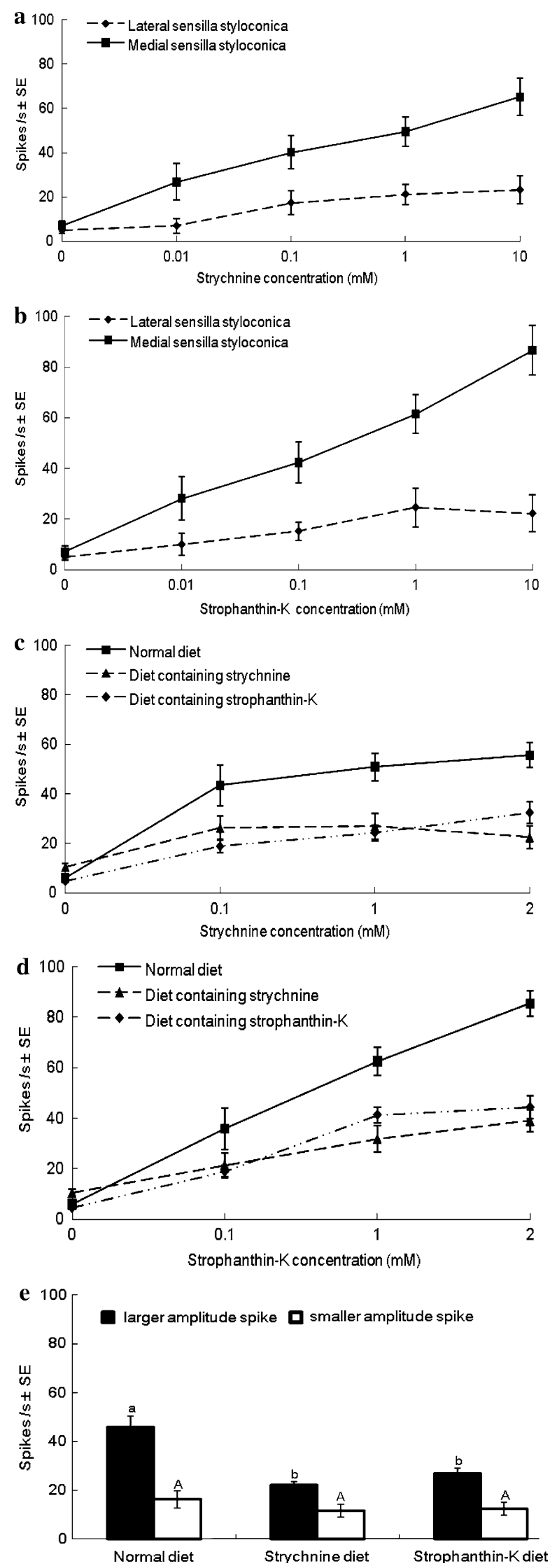

4Fig. 2 a Dose-response curves for strychnine; spike frequencies (spikes/s; mean $\pm \mathrm{SE}, n=12$ ) of the deterrent neurons in the two sensilla styloconica of $H$. armigera caterpillars reared on normal artificial diet from neonate to fifth instar. b Dose-response curves for strophanthin-K; spike frequencies (spikes/s; mean $\pm \mathrm{SE}, n=12$ ) of the deterrent neurons in the two sensilla styloconica of $H$. armigera caterpillars reared on normal artificial diet from neonate to fifth instar. c Dose-response curves for strychnine; spike frequencies (spikes/s; mean $\pm \mathrm{SE}, n=12$ ) of the deterrent neuron in medial sensilla styloconica of $H$. armigera caterpillars reared on normal artificial diet, artificial diet containing strychnine or artificial diet containing strophanthin-K during development to the fifth instar. d Doseresponse curves for strophanthin-K; spike frequencies (spikes/s; mean $\pm \mathrm{SE}, n=12$ ) of the deterrent neuron in medial sensilla styloconica of $H$. armigera caterpillars reared on normal artificial diet, artificial diet containing strychnine or artificial diet containing strophanthin-K during development to the fifth instar. e Spike frequencies (spikes/s; mean $\pm \mathrm{SE}, n=12$ ) of the two different neurons activated by $1 \mathrm{mM}$ strophanthin-K of $H$. armigera caterpillars reared on normal artificial diet, artificial diet containing strychnine or artificial diet containing strophanthin-K during development to the fifth instar. Bar values that have no letters in common differ significantly $(t$ test, $P<0.05)$

germ-fraction of the artificial diet as apigenin-based flavonoids (Renwick and Huang 1995; Huang and Renwick 1995b, 1997). Several studies documented that dietary experience influenced food selection behavior of other plant-feeding insect species (Jermy et al. 1967; Schoonhoven 1967; Bernays and Chapman 1987; Renwick and Lopez 1999; Glendinning et al. 2001a; Bernays and Singer 2005).

Strychnine is an alkaloid found in the seeds of the Strychnos nux-vomica tree. Strophanthin-K is a cardiac glycoside strophanthin mixture, obtained from the plant Strophanthus kombé. The two chemicals are not found in the known host plants of $H$. armigera. Therefore, they are "novel" compounds for the generalist $H$. armigera. In this study we used two different substrates in the behavioral experiments: cotton leaf disks and pepper fruit disks. Both cotton and pepper belong to the host plant range of H. armigera (Chen 1999). The advantage of pepper fruit disks as the substrate was that the chemical solution was taken up evenly by the disks, whereas on cotton leaf disks the compounds were most likely present in a concentrated surface layer. Nevertheless, we obtained similar behavioral results by using the two different substrates. We found that the normal artificial diet-reared $H$. armigera larvae were strongly deterred by both chemicals. However, after exposure to one of the two chemicals from neonate to the penultimate molt, caterpillars become habituated to both chemicals (Fig. 1a-e). This is a form of "cross-habituation," which was defined as the phenomenon that dietary exposure of larvae to certain deterrent compounds can profoundly affect behavioral responses to 


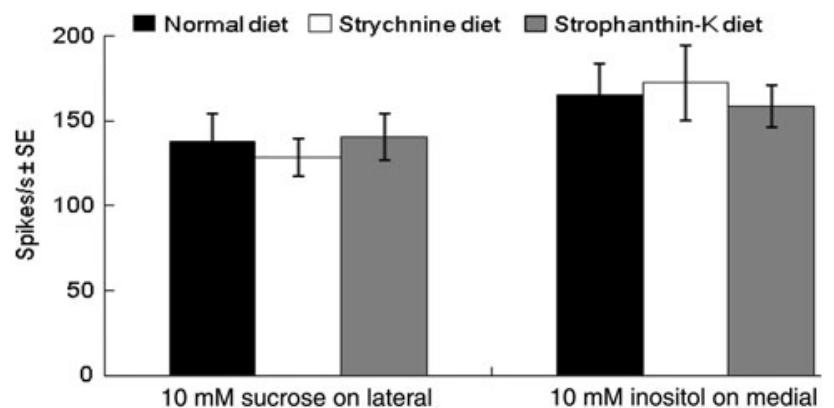

Fig. 3 Spike frequencies (spikes/s; mean \pm SE, $n=12$ ) of the neuron in the lateral sensilla styloconica activated by $10 \mathrm{mM}$ sucrose and the neuron in the medial sensilla styloconica activated by $10 \mathrm{mM}$ inositol of $H$. armigera caterpillars reared on normal artificial diet, artificial diet containing strychnine or artificial diet containing strophanthin-K during development to the fifth instar

other, chemically unrelated deterrents (Huang and Renwick 1995b).

The habituation observed may be based on several possible mechanisms. First, long-term contact of the deterrents could desensitize the taste neurons responding to deterrents, thus reducing the intensity of sensory input underlying the aversive behavioral response. The oligophagous Manduca sexta exhibited a reduced behavioral response to salicin after $72 \mathrm{~h}$ of dietary exposure to a salicin-containing diet. This behavioral adaptation to salicin was associated with a significant desensitization of the salicin-responsive taste cell in the lateral syloconic sensilla (Schoonhoven 1969). There are other examples of changes in the peripheral gustatory system as a result of dietary exposure, likewise associated with habituation. Manduca sexta fed an artificial diet with caffeine or salicin had reduced behavioral responsiveness to the same compounds. The experience-induced reduction in behavioral responsiveness to caffeine was associated with reduced peripheral taste responsiveness, but that to salicin was not, leading to the inference that experience-induced reduction in behavioral responsiveness to salicin was mediated centrally (Glendinning and Hills 1997; Glendinning et al. 1999, 2002). Compared with caterpillars of $P$. rapae reared on their host plant cabbage (Brassica oleracea L.), caterpillars reared on an artificial diet had a reduced sensitivity of deterrent neurons in medial sensilla styloconica to the structurally diverse chemicals chlorogenic acid, naringin and strychnine (Zhou et al. 2009). Caterpillars of $P$. brassicae, also an oligophagous insect on Brassicaceae, were less sensitive to $5 \mathrm{mM}$ chlorogenic acid when reared on an artificial diet than cabbage-reared caterpillars (van Loon 1990). Second, herbivorous insects can increase their detoxification activity directed against certain plant toxins when they have a prolonged ingestion of such compounds. For example, Manduca sexta can induce the P450-mediated detoxification activities and thus increase the consumption of nicotine, the dominant allelochemical of its favorite host plants, Nicotiana species (Snyder and Glendinning 1996). In Spodoptera frugiperda, the increased consumption of the toxin indole 3-carbinol correlated with the induction of P450 enzymes (Glendinning and Slansky 1995). Third, chronic exposure to deterrents can result in synaptic plasticity in the processing of gustatory information in the central nervous system. The exposure to specific chemicals for a period of time might activate learning processes in the central nervous system, changing the behavioral responsiveness to taste stimuli (Sclafani 1991; Glendinning et al. 2001b).

In this study we tested if long-term exposure to two deterrents (strychnine and strophanthin-K) desensitized taste neurons in $H$. armigera larvae that showed excitatory responses to these allelochemicals. Caterpillars commonly have sensilla harboring deterrent-sensitive neurons in epipharyngeal sensilla and maxillary sensilla located on both the galea and the palp tips (Glendinning et al. 1998; Schoonhoven and van Loon 2002). The lateral and medial sensilla styloconica on the maxillary galea play a decisive role in detecting plant chemicals of the leaf interior (Schoonhoven and van Loon 2002); therefore, we focused on the latter sensilla in this study. Taste neurons in the epipharyngeal sensilla have the same specificity as the corresponding taste neurons in the styloconic sensilla of the maxillary galea in all cases studied and seem to control food swallowing rather than food selection (Schoonhoven and van Loon 2002). As the response of the medial sensilla styloconica to the two deterrents was very strong while that of the lateral sensilla styloconica was weak (Fig. 2), we focused on the deterrent neurons in the medial sensilla styloconica. The electrophysiological tests showed that the sensitivity of deterrent neurons in the medial sensilla styloconica to the two chemicals decreased significantly when the caterpillars were exposed from neonate until the penultimate molt (Figs. 2, 4). Furthermore, the mixture of strychnine and strophanthin-K showed that one deterrent neuron in the medial sensilla styloconica responded to both strychnine and strophanthin-K. Further analyses showed that this neuron, of the two neurons responding to strophanthin-K, was significantly less sensitive after long-term exposure to the two chemicals (Fig. 2e). Our interpretation of these findings is that "cross-habituation" could be tracked down to the same gustatory channel, and therefore to cross-desensitization. An alternative interpretation of our findings is a general decrease of sensitivity of the maxillary taste system. However, we demonstrate that the sensitivity of the neurons responsive to the feeding stimulants sucrose (in the lateral sensillum) and inositol (in the medial sensillum) did not change when the caterpillars experienced the diets containing the two deterrents (Figs. 3, 4), making 
Fig. 4 Exemplary recordings of electrophysiological activity in medial sensilla styloconica on the maxillary galea of fifth instar $H$. armigera reared on normal artificial diet, on artificial diet containing strychnine or on artificial diet containing strophanthin-K. Stimulus solutions tested and dietary experience: a Control (KCl $2 \mathrm{mM}$ ), normal artificial diet-reared caterpillars.

b Strychnine $1 \mathrm{mM}$, normal artificial diet-reared caterpillars. c Strychnine $1 \mathrm{mM}$, caterpillars reared on artificial diet containing strychnine. d Strychnine $1 \mathrm{mM}$, caterpillars reared on strophanthin-Kcontaining diet. e Strophanthin-K $1 \mathrm{mM}$, normal artificial dietreared caterpillars.

f Strophanthin-K $1 \mathrm{mM}$, caterpillars reared on artificial diet containing strychnine. g Strophanthin-K $1 \mathrm{mM}$, caterpillars reared on artificial diet containing strophanthin-K. h Mixture of strychnine and strophanthin-K (both $1 \mathrm{mM}$ ), normal artificial diet-reared caterpillars. The onset of the stimulations occurred at the beginning of each trace. Arrows "1" and " 2 " point at two different spike types that strophanthin-K or its mixture with strychnine elicited from the medial sensilla styloconica. Arrow "1" refers to the more abundant larger amplitude spike type, arrow " 2 " refers to the less abundant smaller amplitude spike type. i Inositol $10 \mathrm{mM}$, normal artificial-diet reared caterpillars. j Inositol $10 \mathrm{mM}$, caterpillars reared on artificial diet containing strychnine.

k Inositol $10 \mathrm{mM}$, caterpillars reared on artificial diet containing strophanthin-K

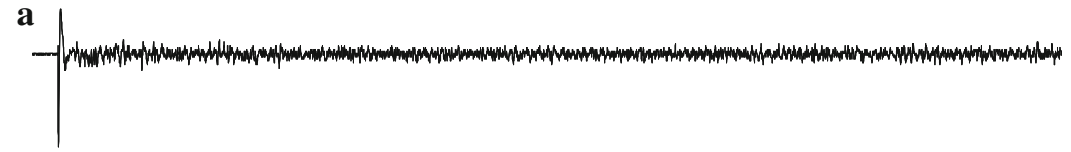

b

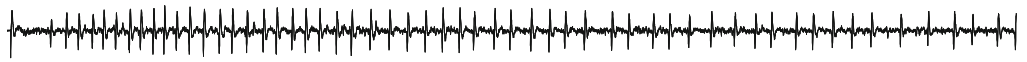

c
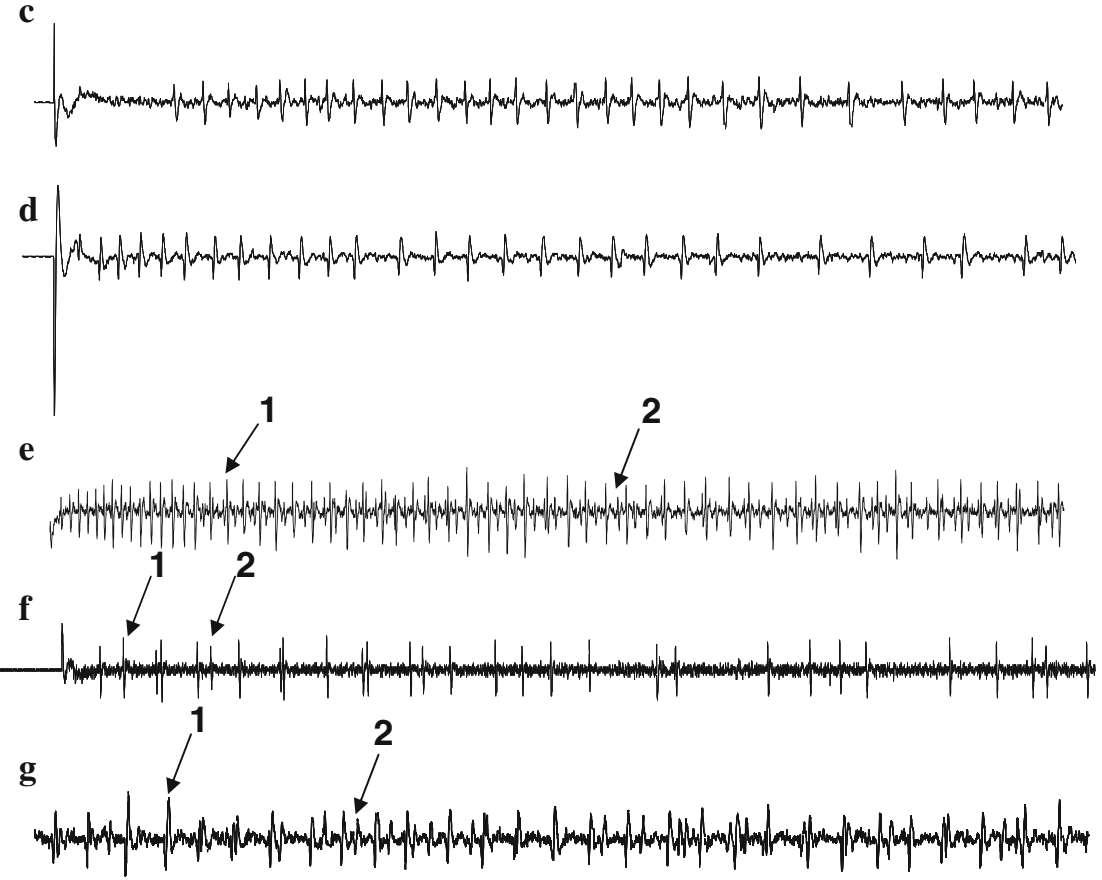

h

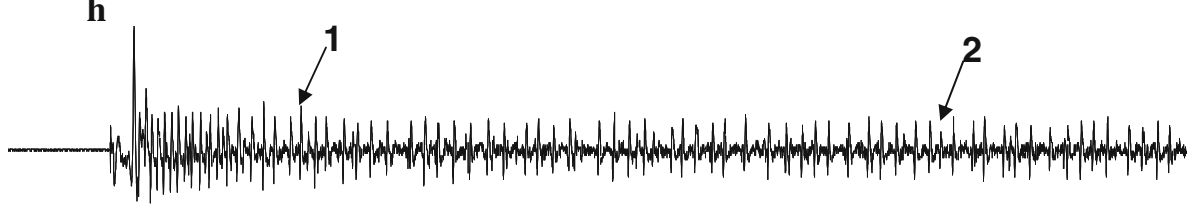

i

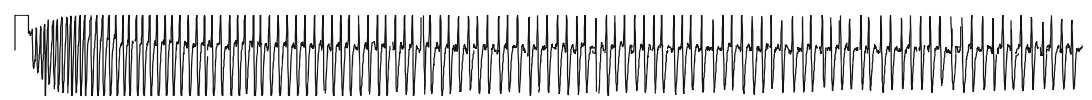

j

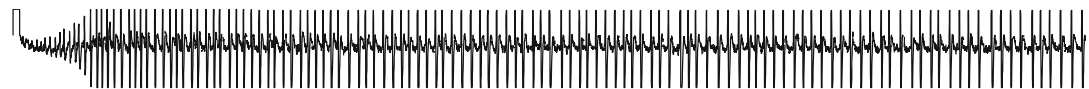

k

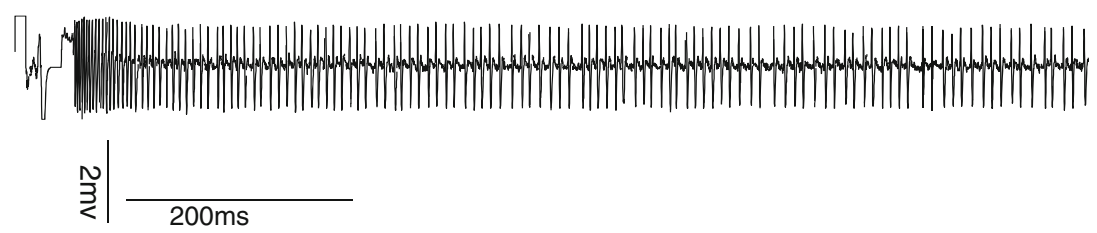

the alternative interpretation unlikely. Our results showed that dietary experience affects the chemosensory sensitivity to the two chemically distinct classes of deterrent chemicals. Different scenarios could account for such a cross-desensitization: (1) the two chemicals possibly bind to the same promiscuous taste receptor protein although 
their chemical structures are quite different; (2) the two chemicals bind to different receptor molecules, but there could be a common step in the signal-transduction pathway occurring after Gr-ligand interactions, as proposed for the specialist $P$. rapae (Zhou et al. 2009).

Our combined results suggest that the reduced response at the behavioral level is at least partly explained by reduced taste neuron sensitivity. In addition, we found generalization (cross-habituation and cross-desensitization) between two structurally unrelated compounds. Our experimental methods do not allow a conclusion on the contribution of plasticity in the central nervous system or a possible role of increased detoxification activity to the behavioral changes observed. The clear link between reduced taste neuron activity and reduced taste-mediated behavioral responsiveness implies a causal effect of chemosensory plasticity on modified food selection behavior.

Acknowledgments We thank Yun-Hua Yan and Ling-Qiao Huang for assistance in rearing the moths and preparing the experiments. This work was supported by the National Basic Research Program of China (grant no. 2006CB102006), the National Natural Science Foundation of China (grant no. 30925026, 30621003) and the Royal Dutch Academy of Arts and Sciences (grant 05PhD04).

Open Access This article is distributed under the terms of the Creative Commons Attribution Noncommercial License which permits any noncommercial use, distribution, and reproduction in any medium, provided the original author(s) and source are credited.

\section{References}

Bernays EA, Chapman RF (1987) The evolution of deterrent responses in plant-feeding insects. In: Bernays EA, Chapman RF, Stoffolano JG Jr (eds) Perspectives in chemoreception and behavior. Springer, New York, pp 159-173

Bernays EA, Singer MS (2005) Taste alteration and endoparasites. Nature 436:476

Bernays EA, Oppenheim S, Chapman RF, Kwon H, Gould F (2000) Taste sensitivity of insect herbivores to deterrents is greater in specialists than in generalists: a behavioral test of the hypothesis with two closely related caterpillars. J Chem Ecol 26:547-563

Chapman RF, Bernays EA (1989) Insect behavior at the leaf surface and learning as aspects of host plant selection. Cell Mol Life Sci 45:215-222

Chen YX (1999) Fauna Sinica: insecta, Lepidoptera Noctuidae. Science Press, Beijing

Dahanukar A, Hallem EA, Carlson JR (2005) Insect chemoreception. Curr Opin Neurobiol 15:423-430

Dethier VG (1993) The role of taste in food intake: a comparative view. In: Simon SA, Roper SD (eds) Mechanisms of taste transduction. CRC, Boca Raton, pp 3-25

Fitt GP (1989) The ecology of Heliothis species in relation to agroecosystems. Annu Rev Entomol 34:17-52

Glendinning JI, Gonzalez NA (1995) Gustatory habituation to deterrent allelochemicals in a herbivore-concentration and compound specificity. Anim Behav 50:915-927
Glendinning JI, Hills TT (1997) Electrophysiological evidence for two transduction pathways within a bitter-sensitive taste receptor. J Neurosci 78:734-745

Glendinning JI, Slansky F Jr (1995) Consumption of a toxic food by caterpillars increases with dietary exposure: support for a role of induced detoxification enzymes. J Comp Physiol A 176:337-345

Glendinning JI, Valcis S, Timmermann BN (1998) Maxillary palps can mediate taste rejection of plant allelochemicals by caterpillars. J Comp Physiol A 183:35-43

Glendinning JI, Ensslen S, Eisenberg ME, Weiskopf P (1999) Dietinduced plasticity in the taste system of an insect: localization to a single transduction pathway in an identified taste cell. J Exp Biol 202:2091-2102

Glendinning JI, Brown H, Capoor M, Davis A, Gbedemah A, Long E (2001a) A peripheral mechanism for behavioral adaptation to specific "bitter" taste stimuli in an insect. J Neurosci 21:3688-3696

Glendinning JI, Domdom S, Long E (2001b) Selective adaptation to noxious foods by a herbivorous insect. $\mathrm{J}$ Exp Biol 204:3355-3367

Glendinning JI, Davis A, Ramaswamy S (2002) Contribution of different taste cells and signaling pathways to the discrimination of "bitter" taste stimuli by an insect. J Neurosci 22:7281-7287

Hodgson ES, Lettvin JY, Roeder KD (1955) Physiology of a primary receptor unit. Science 122:417-418

Huang XP, Renwick JAA (1995a) Chemical and experimental basis for rejection of Tropaeolum majus by Pieris rapae larvae. J Chem Ecol 21:1601-1617

Huang XP, Renwick JAA (1995b) Cross habituation to feeding deterrents and acceptance of a marginal host-plant by Pieris rapae larvae. Entomol Exp Appl 76:295-302

Huang XP, Renwick JAA (1997) Feeding deterrents and sensitivity suppressors for Pieris rapae larvae in wheat germ diet. J Chem Ecol 23:51-70

Hugentobler U, Renwick JAA (1994) Effects of plant nutrition on the balance of insect relevant cardenolides and glucosinolates in Erysimum cheiranthoides. Oecologia 102:95-101

Jermy T, Hanson FE, Dethier VG (1967) Induction of specific food preference in lepidopterous larvae. Entomol Exp Appl 41:211-230

Messchendorp L, van Loon JJA, Gols GJZ (1996) Behavioural and sensory responses to drimane antifeedants in Pieris brassicae larvae. Entomol Exp Appl 79:195-202

Miles CI, del Campo ML, Renwick JAA (2005) Behavioral and chemosensory responses to a host recognition cue by larvae of Pieris rapae. J Comp Physiol A 191:147-155

Renwick JAA, Huang XP (1995) Rejection of host-plant by larvae of cabbage butterfly - diet-dependent sensitivity to an antifeedant. J Chem Ecol 21:465-475

Renwick JAA, Huang XP (1996) Development of sensitivity to feeding deterrents in larvae of Pieris rapae. Entomol Exp Appl 80:90-92

Renwick JAA, Lopez K (1999) Experience-based food consumption by larvae of Pieris rapae: addiction to glucosinolates? Entomol Exp Appl 91:51-58

Schoonhoven LM (1967) Loss of host plant specificity by Manduca sexta after rearing on an artificial diet. Entomol Exp Appl 10:270-272

Schoonhoven LM (1969) Sensitivity changes in some insect chemoreceptors and their effect on food selection behaviour. Proc Koninkl Ned Akad Wet C 72:491-498

Schoonhoven LM (1978) Long-term sensitivity changes in some insect taste receptors. Arzneimittel-Forsch Drug Res 28:2367

Schoonhoven LM, van Loon JJA (2002) An inventory of taste in caterpillars: each species its own key. Acta Zool Acad Sci Hung 48:215-263 
Sclafani A (1991) Conditioned food preferences. Bull Psychon Soc 29:256-260

Sherman PW, Reeve HK, Pfenning DW (1997) Recognition systems. In: Krebs JR, Davies NB (eds) Behavioral ecology: an evolutionary approach. Blackwell Science, Oxford, pp 69-96

Snyder MJ, Glendinning JI (1996) Causal connection between detoxification enzyme activity and consumption of a toxic plant compound. J Comp Physiol A 179:255-261

Tang DL, Wang CZ, Luo LE, Qin JD (2000) Comparative study on the responses of maxillary sensilla styloconica of cotton bollworm Helicoverpa armigera and oriental tobacco budworm H. assulta larvae to phytochemicals. Sci China C Life Sci 43:606-612

Tang QB, Jiang JW, Yan YH, van Loon JJA, Wang CZ (2006) Genetic analysis of larval host-plant preference in two sibling species of Helicoverpa. Entomol Exp Appl 118:221-228

van Loon JJA (1990) Chemoreception of phenolic acids and flavonoids in larvae of two species of Pieris. J Comp Physiol A $166: 889-899$

van Loon JJA, Schoonhoven LM (1999) Specialist deterrent chemoreceptors enable Pieris caterpillars to discriminate between chemically different deterrents. Entomol Exp Appl 91:29-35 van Loon JJA, Tang QB, Wang HL, Wang CZ, Zhou DS, Smid HM (2008) Tasting in plant-feeding insects: from single compounds to complex natural stimuli. In: Newland PL, Cobb M, MarionPoll F (eds) Insect taste. Taylor and Francis, Abingdon, pp 103-126

Wang CZ, Dong JF, Tang DL, Zhang JH, Li W, Qin J (2004) Host selection of Helicoverpa armigera and $H$. assulta and its inheritance. Prog Nat Sci 14:880-884

Wu KJ, Gong PY (1997) A new and practical artificial diet for the cotton bollworm. Entomologia Sinica 4:277-282

Zhao XC, Yan YH, Wang CZ (2006) Behavioral and electrophysiological responses of Helicoverpa assulta, H. armigera (Lepidoptera: Noctuidae), their F1 hybrids and backcross progenies to sex pheromone component blends. J Comp Physiol A 192:1037-1047

Zhou DS, Wang CZ, van Loon JJA (2009) Chemosensory basis of behavioural plasticity in response to deterrent plant chemicals in the larva of the small cabbage white butterfly Pieris rapae. J Insect Physiol 55:788-792 